\title{
The Contributions of Postmodernism Methodology as a Prevailing Practice on Ground of Humanities Sciences
}

\author{
Mohammad Khosravishakib
}

Department of Persian Language and Literature, Human Science Faculty, Lorestan University, I. R. Iran

\begin{abstract}
Postmodernity is a condition or a state of being associated with changes to institutions and conditions and with social and political results and innovations, globally but especially in the West since the 1960s, whereaspostmodernism is an aesthetic, literary, political or social philosophy, the "cultural and intellectual phenomenon", especially since the 1920s' new movements in the arts and literature. Both of these terms are used by philosophers, social scientists and social critics to refer to aspects of contemporary culture, economics and society that are the result of features of late 20th century and early 21 st century life, including the fragmentation of authority and the commoditization of knowledge. In this paper it has been tried to show the connection between this approach and other humanity sciences so that crystallized the kingdom of this overall movement.
\end{abstract}

Keywords Postmodernism, literature, art, music, movie, philosophy

\section{Introduction}

Postmodernity has been saidto have gone through two relatively distinct phases, the first beginning in the late 1940s and 1950s and ending with the Cold War, and the second beginning at the end of the Cold War, marked by the spread of cable television and "new media" based on digital means of information dissemination and broadcast."The first phase of postmodernity overlaps the end of modernity and is regarded by manyas being part of the modern period".(Harvey; 1990. P.9) Television became the primary news source, manufacturing decreased in importance in the economies of Western Europe and the United States but trade volumes increased within the developed core. In 1967 -1969 a crucial cultural explosion took place within the developed world as the baby boom generation, which had grown up with postmodernity as their fundamental experience of society, demanded entrance into the political, cultural and educational power structure. A series of demonstrations and acts of rebellionrepresented the opposetion of the young to the policies and perspectives of the previous age. "The second phase of postmodernity is defined by "digitally" - the increasing power of personal and digital means of communication including fax machines, modems, cable and high speed internet, which has altered the condition of postmodernity dramatically. Digital production of information allows individuals to manipulate virtually every aspect of the media

*Corresponding author:

Khosravi_shakib@yahoo.com (Mohammad Khosravishakib)

Published online at http://journal.sapub.org/arts

Copyright (C) 2012 Scientific \& Academic Publishing. All Rights Reserved environment". (Harvey; 1990. P. 13) This has brought producers into conflict with consumers over intellectual capital and intellectual property and led to the creation of a new economy whose supporters argue that the dramatic fall in information costs will alter society fundamentally. Where modernists hoped to unearth universals or the fundamentals of art, postmodernism aims to unseat them, to embrace diversity and contradiction. (Hoover; 1994. P.24) A postmodern approach to art thus rejects the distinction between low and high art forms. The postmodern creator, in turn, is free to combine any elements or styles in a work, even in ways that are counter to or irrelevant to the apparent function of the object. "Postmodern style is often characterized by eclecticism, digression, collage, pastiche, irony, the return of ornament and historical reference, and the appropriation of popular media". (Waugh; 1992. P. 43) Some artistic movements commonly called postmodern are pop art, architectural deconstructivism, magical realism in literature, maximalism, and neo-romanticism. It rejects rigid genre boundaries and promotes parody, irony, and playfulness, commonly referred to as jouissance by postmodern theorists. Unlike modern art, postmodern art does not approach this fragmentation as somehow faulty or undesirable, but rather celebrates it. Post-modernity, in attacking the perceived elitist approach of Modernism, sought greater connection with broader audiences. (Jameson; 1991. P. 62) This is often labeled "accessibility" and is a central point of dispute in the question of the value of postmodern art. It has also embraced the mixing of words with art, collage and other movements in modernity, in an attempt to create more multiplicity of medium and message. Much of these centers on a shift of basic subject matter: postmodern artists regard the mass 
media as a fundamental subject for art, and use forms, tropes, and materials such as banks of video monitors, found art, and depictions of media objects as focal points for their art. (Lyotard; 1988. P. 55) Postmodernism's critical stance is interlinked with presenting new appraisals of previous works. Post-modernism also elevated the importance of cinema in artistic discussions, placing it on a peer level with the other fine arts. This is both because of the blurring of distinctions between "high" and "low" forms, and because of the recognition that cinema represented the creation of simulacra which was later duplicated in the other arts.

\section{Graphic and Approach of Postmodernism}

Postmodernism in graphic design for the most part has been a visual and decorative movement. Many designers and design critics contend that postmodernism, in the literary or architectural sense of the term, never really impacted graphic design as it did these other fields. Alternatively, some argue that it did but took on a different persona. But when all was said and done, the various notions of the postmodern in the various design fields never really stuck to graphic design as it did with architecture. Some argue that the "movement" had little to no impact on graphic design. More likely, it did, but more in the sense of a continuation or re-evaluation of the modern. Some would argue that this continuous re- evaluation is also just a component of the design process - happening for most of the second half of the 20th century in the profession. Since it was ultimately the work of graphic designers that inspired pop artists like Warhol and Liechtenstein, and architects like Robert Venturi and Denise Scott-Brown, it could be argued that graphic design practice and designs may be the root of Postmodernism. Graphic design saw a massive popular rising at the end of the seventies in form of Graffiti and Hip Hop culture's rise. Graphic forms of expression became a vast everyday hobby among school kids all around the developed western countries. Alongside this 'movement', that took rebellious and even criminal cultural forms, was born the mass hobby of coding computer graphics. This phenomenon worked as a stepping stone towards the graphic infrastructure that is applied in the majority of computer interfaces today. Theoretical and conceptual discourse in graphic design has always been a bit naive compared to older more established cultural practices. For example, all designers have been, and continue to be taught, the history of type design in terms of the five families of type: Oldstyle, Transitional, Modern, Egyptian, and Contemporary. This nineteenth century terminology devised by type founders is completely out of sync with period classifications used in the humanities. As such, it disconnects type design from our general cultural history. Given this type of foundation, it should come as no surprise that contemporary design discourse is also out of sync with that of architecture, literature, and art. (Magliola; 1997.P.32-34) Graphic designers are caught up in a media stream that is very wide and fast, but not very deep. The only way to navigate in it is to go faster or slower than the stream. To go faster you must be at the forefront of technology and fashion, both of which are changing at an unprecedented rate. To go slower you need an understanding of context through history and theory. Graphic designers are predisposed to going faster or slower according to their experience and inclination, but mostly they are getting swept along in the currents of pop mediocrity.

\section{Music and Dance in Postmodernism Kingdom}

Postmodern music is both a musical style and a musical condition. As a musical style, postmodern music contains characteristics of postmodern art; eclecticism in musical form and musical genre, combining characteristics from different genres, or employing jump-cut sectionalization, such as blocks. It tends to be self-referential and ironic, and it blurs the boundaries between "high art" and kitsch. In this sense, postmodern music does not have any one particular style or characteristic, and is not necessarily postmodern in style or technique. Although not as widespread or influential as other art forms, postmodern music and dance have nevertheless developed many of the key traits of postmodernism, sometimes in their most radical aspects, both building upon and working against such modernist figures as Arnold Schönberg, Igor Stravinsky, and Pierre Boulez in music, and George Balanchine, Martha Graham, and Merce Cunningham in dance. Radically experimental postmodernist composers such as Karlheinz Stockhausen, IannisXenakis, and GyörgyLigeti have gone beyond modernism in dislocating the classical harmonies and replacing them with ever more complex, nearly unmusical, sounds and noises. (Mchale; 1987. P. 66-67) The same formal experimentation can often be found in postmodernist dance. Postmodernist dance is, however, particularly characterized by the collapse of boundaries between "high" dance (classical ballet and modern dance) and "popular" dance (jazz dance, folk and tribal dance, ballroom dancing, break and line dancing, and Broadway musical choreography), as choreographers fused their various styles and movements. Among the most prominent representatives of the postmodern dance scene are Bill T. Jones, Twyla Tharp, and Mark Morris. Some choreographers have gone even farther afield, incorporating movements from the martial arts, sports, acrobatics, mime, games, and even the mundane physical activities of everyday life. These trends are found in postmodernist (classical) music as well, from the usage of elements of jazz and rock and roll to the incorporation of street or elevator noises. Dance, however, became quite literally more a part of the world, as choreographers developed architecturally inspired, site-specific works. At the same time, dance increasingly became a part of the broader forms of performance art and 
multimedia art, as choreography was linked to political concerns and combined with video, text, and other media. One might say that the choreography of postmodern dance is the choreography of postmodernism itself, its aesthetics and its politics, including its politics of aesthetics defined by the lack of a single consensus of taste.

\section{Literature and Approach of Postmodernism}

Postmodern literature, like postmodernism as a whole, is hard to define and there is little agreement on the exact characteristics, scope, and importance of postmodern literature. But as is often the case with artistic movements, postmodern literature is commonly defined in relation to its precursor. For example, instead of the modernist quest for meaning in a chaotic world, the postmodern author avoids, often playfully, the possibility of meaning, and the postmodern novel is often a parody of this quest. Postmodern authors also tend to celebrate chance over craft, and further employ metafiction to undermine the writer's authority. Another characteristic of postmodern literature is the questioning of distinctions between high and low culture through the use of pastiche, the combination of subjects and genres not previously deemed fit for literature.(Foucault; 1983. P. 16) Postmodern literature argues for expansion, the return of reference, the celebration of fragmentation rather than the fear of it, and the role of reference itself in literature. While drawing on the experimental tendencies of authors such as Ernest Hemingway and William Faulkner in English, and Jorge Luis Borges in Spanish - writers who were taken as influences by American postmodern authors such as Norman Mailer, Thomas Pynchon, Kurt Vonnegut, Don DeLillo, John Barth, William Gaddis, David Foster Wallace, and Paul Auster - the advocates of postmodern literature argue that the present is fundamentally different from the modern period, and therefore requires a new literary sensibility.

\section{Cinema In way of Postmodernism}

Post modernism in film can loosely be used to describe a film in which the audience's suspension of disbelief is destroyed, or at the very least toyed with, in order to free the audience's appreciation of the work, and the creator's means with which to express it. The cornerstones of conventional narrative structure and characterization are changed and even turned on their head in order to create a work whose internal logic forms its means of expression. Though a popular movement in theatre, particularly with Bertolt Brecht's epic theatre, post-modernist film didn't break into the mainstream until the advent of the French New Wave in the 1950s and 60 's, with such films as Jean-Luc Godard's À bout de souffle. Luis Buñuel and Salvador Dalí's 1928 surrealist short Un ChienAndalou could be argued as a post-modernist film however its extreme deconstruction of structure and char- acter make its meaning almost entirely arbitrary, and thus to still convey some desired meaning post-modernist films still maintain some conventional elements in order for the audience to grasp them. Two such examples are Jane Campion's Two Friends, in which the story of two school girls is showed in episodic segments arranged in reverse order; and KarelReisz'sThe French Lieutenant's Woman, in which the story being played out on the screen is mirrored in the private lives of the actors playing it, which we also see. By making small but significant changes to the conventions of cinema the artificiality of the experience and the world presented is emphasized in the audience's mind, in order to remove them from the conventional emotional bonds they have to the subject matter, and to give them a new view of it. Postmodernism applied to film has four main concepts to think about.

A- Simulation- taking what has been made, and reusing it. Through pastiche; intentionally replicated style or through parody; drawing irony from styles to make new styles.

B- Pre - fabrication - similar to simulation, draws even closer to already existing and noticeable scenes, and simply reuses them, in narrative, dialogue, etc.

C- Intertextuality- similar to prefabrication, it's a text that draws upon other texts. The clearest example is the blatant remake.

D- Bricolage- building a film likes a collage of different film styles and genres. (Hayward; 1996. P. 81-89)

\section{Political Issues in Way Postmodernism}

According to postmodernist political theorists, there are many situations which are considered political in nature that cannot be adequately discussed in traditional realist and liberal approaches to political science. Some examples they cite include the situation of a "draft-age youth whose identity is claimed in national narratives of 'national security' and the universalizing narratives of the "rights of man," of "the woman whose very womb is claimed by the irresolvable contesting narratives of 'church,' 'paternity,' 'economy,' and 'liberal polity.' They argue that in these cases, there are no fixed categories, stable sets of values, or common sense meanings to be understood in their scholarly exploration. They contend that liberal approaches do not aid in understanding these types of situations; arguing that there is no individual or social or institutional structure whose values can impose a meaning or interpretive narrative. Postmodernists argue that meaning and interpretation in these types of situations is always uncertain and arbitrary. They contend that the power in effect here is not that of oppression, but that of the cultural and social implications around them, which they say creates the framework within which they see themselves, which creates the boundaries of their possible courses of action. (Lyotard; 1984. P. 43-51) Postmodern political scientists, such claim that in these marginal sites it is impossible to construct a coherent narrative, or story, about what is really taking place without including contesting and 
contradicting narratives, and still have a "true" story from the perspective of a "sovereign subject," who can dictate the values pertinent to the "meaning" of the situation. By regarding them in this way, deconstructive readings attempt to uncover evidence of ancient cultural biases, conflicts, lies, tyrannies, and power structures, such as the tensions and ambiguity between peace and war, lord and subject, male and female, which serve as further examples of Derrida's binary oppositions in which the first element is privileged, or considered prior to and more authentic, in relation to the second. Examples of postmodern political scientists include post-colonial writers such as Frantz Fanon, feminist writers such as ShahrnooshParsipoor in Iran, and postpositive theorists such as Akhavan and Shamloo in contemporary Persian poetry.

\section{Language and Process of Postmodernism}

Important to postmodernism's view of language is the focus on the implied meaning of words and the power structures that are accepted as part of the way words are used, from the use of the word "Man" with a capital "M" to refer to humanity collectively, to the default of the word "he" in English as a pronoun for a person of gender unknown to the speaker. However, this is merely the most obvious example of the changing relationship between diction and discourse which postmodernism presents.(Barthes; 1968. P. 51) An important concept in postmodernism's view of language is the idea of "play" text. In the context of postmodernism, play means changing the framework which connects ideas, and thus allows the turning, of a metaphor or word from one context to another, or from one frame of reference to another. Since, in postmodern thought, the "text" is a series of "markings" whose meaning is imputed by the reader, and not by the author, this play is the means by which the reader constructs or interprets the text, and the means by which the author gains a presence in the reader's mind. Play then involves invoking words in a manner which undermines their authority, by mocking their assumptions or style, or by layers of misdirection as to the intention of the author. Roland Barthes argued this concept, and coined it 'Death of the Author'; this allows for 'freedom of the reader'. Barthes is well known for having stated, "It is language that speaks, not the author". (barthes; 1975. P. 43) Another key concept is the view that people are, essentially, blank slated linguistically, and that social acclimation, cultural factors, habituation and images are the primary ways of shaping the structure of how people speak. This view of writing is criticized by some, who regard it as needlessly difficult and obscure, and a violation of the implicit contract of lucidity between author and reader: that an author has something to communicate, and shall choose words which transmit the idea as transparently as possible to the reader.

\section{Postmodernism in Philosophy}

Postmodern philosophy is a radical criticism of Western philosophy, because it rejects the universalizing tendencies of philosophy. It applies to movements that include poststructuralism, deconstruction, multiculturalism, neo- relativism, neo-Marxism, gender studies and literary theory. It emerged beginning in the 1950s as a rejection of doctrines such as positivism, Social Darwinism, materialism and objective idealism. Postmodern philosophy emphasizes the importance of power relationships, personalization and discourse in the "construction" of truth and world views. In this context it has been used by critical theorists to assert that postmodernism is a break with the artistic and philosophical tradition of the Enlightenment, which they characterize as a quest for an ever-grander and more universal system of aesthetics, ethics, and knowledge. Postmodern philosophy draws on a number of approaches to criticize Western thought, including historicism, and psychoanalytic theory.Postmodern philosophy is criticized for prizing irony over knowledge, and giving the irrational equal footing with the rational. (Foucalt; 1983. P. 32-33) In terms of frequently cited works, postmodernism and post-structuralism overlap quite significantly. Some philosophers, such as Jean- François Lyotard, can legitimately be classified into both groups. This is partly because both modernism and structuralism owe much to the Enlightenment project. Structuralism has a strong tendency to be scientific in seeking out stable patterns in observed phenomena - an epistemological attitude which is quite compatible with Enlightenment thinking, and incompatible with postmodernists. At the same time, findings from structuralism analysis carried a somewhat antiEnlightenment message, revealing that rationality can be found in the minds of "savage" people, just in forms differing from those that people from "civilized" societies are used to seeing. Implicit here is a critique of the practice of colonialism, which was partly justified as a "civilizing" process by which wealthier societies bring knowledge, manners, and reason to less "civilized" ones.

Post-structuralism, emerging as a response to the structuralists' scientific orientation, has kept the cultural relativism in structuralism, while discarding the scientific orientations. One clear difference between postmodernism and post structuralism is found in their respective attitudes towards the demise of the project of the Enlightenment: post- structuralism is fundamentally ambivalent, while postmodernism is decidedly celebratory. Another difference is the nature of the two positions. While post-structuralism is a position in philosophy, encompassing views on human beings, language, body, society, and many other issues, it is not a name of an era. Post-modernism, on the other hand, is closely associated with "post-modern" era, a period in the history coming after the modern age.

\section{Conclusions}

The relationship between postmodernity and critical theory, sociology and philosophy is fiercely contested. The 
terms "postmodernity" and "postmodernism" are often hard to distinguish, the former being often the result of the latter. The period has had diverse political ramifications: its "anti-ideological ideas" appear to have been positively associated with the feminist movement, racial equality movements, gay rights movements, most forms of late 20th century anarchism and even the peace movement as well as various hybrids of these in the current anti-globalization movement. Though none of these institutions entirely embraces all aspects of the postmodern movement in its most concentrated definition they all reflect, or borrow from, some of its core ideas. Some authors, such as Lyotard and Baudrillard, believe that modernity ended in the late 20th century and thus have defined a period subsequent to modernity, namely postmodernity, while others, such as Bauman and Giddens, would extend modernity to cover the developments denoted by postmodernity. Others still contend that modernity ended with the Victorian Age in the 1900s.

\section{REFERENCES}

[1] Harvey, D. (1990) The Condition of Postmodernity; Blackwell press, UK.

[2] Barthes, Roland. (1975) The Pleasure of the Text; Hill and Wang press, New York.
[3] Barthes, Roland. (1968) Writing Degree Zero; Hill and Wang press, New York.

[4] Foucault, Michel. (1983) This is Not a Pipe; University of California Press, Uk.

[5] Hoover, Paul. (1994)Postmodern American Poetry: A Norton Anthology; New York press. W. W. Norton \& Company.

[6] Jameson, Fredric (1991) Postmodernism, or, the Cultural Logic of Late Capitalism; University of California Press, Uk.

[7] Lyotard, Jean-Francois (1984) The Postmodern Condition: A Report on Knowledge; University of California Press, Uk.

[8] Lyotard, Jean-Francois (1988). The Postmodern Explained: Correspondence 1982-1985. Ed. Julian Pefanis and Morgan Thomas. University Press, 1997; Oxford: Oxford University Press.

[9] Mchale, Brian. (1987), Postmodernist Fiction; Routledge: London press.

[10] Magliola, Robert (1997), On Deconstructing Life-Worlds: Buddhism, Christianity, Culture; Lafayette, Purdue University Press, 1997; Oxford: Oxford University Press.

[11] Waugh, Patricia. (1992) Postmodernism: A Reader. London press, Edward Arnold.

[12] Hayward, Susan. (1996) "Cinema Studies: The Key Concepts". Third Edition. New York, NY: Routledge press. 